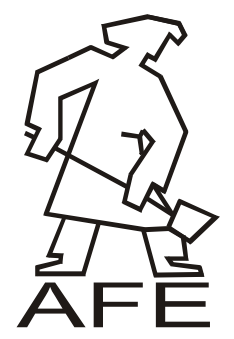

\section{FOUNDRY ENGINEERING}

DOI: $10.2478 /$ afe-2013-0029
ISSN (2299-2944)

Volume 13

Issue $2 / 2013$

\title{
Mould Components Impact on Structure and Quality of Elektron 21 Alloy
}

\author{
B. Dybowski ${ }^{\text {a }}$, A. Kielbus ${ }^{a}$, R. Jarosz ${ }^{\text {b }}$ \\ ${ }^{a}$ Department of Materials Science, Silesian University of Technology, Krasińskiego St. 8, 40-019 Katowice, Poland \\ b ZM „WSK Rzeszów”, Hetmańska St. 120, 35-078 Rzeszów, Poland \\ *Corresponding author. E-mail address: dybowski.bartlomiej@gmail.com
}

Received 16.01.2013; accepted in revised form 03.04.2013

\begin{abstract}
Magnesium alloys due to their low density and high strength-to-weight ratio are promising material for the automotive and aerospace industries. Many elements made from magnesium alloys are produced by means of sand casting. It is essential to investigate impact of the applied mould components on the microstructure and the quality of the castings. For the research, six identical, 100x50x20mm plates has been sand cast from the Elektron 21 magnesium casting alloy. Each casting was fed and cooled in a different way: one, surrounded by mould sand, two with cast iron chills $20 \mathrm{~mm}$ and $40 \mathrm{~mm}$ thick applied, another two with the same chills as well as feeders applied and one with only the feeder applied. Solid solution grain size and eutectics volume fraction were evaluated quantitatively in Met-Ilo program, casting defects were observed on the scanning electron microscope Hitachi S3400N. The finest solid solution grain was observed in the castings with only the chills applied. Non metallic inclusions were observed in each plate. The smallest shrinkage porosity was observed in the castings with the feeders applied.
\end{abstract}

Keywords: Metallography, Elektron 21 alloy, Quantitative metallography, Casting defects, Mould technology

\section{Introduction}

Magnesium alloys are one of the lightest structural materials[1]. Their low density and high mechanical properties provide specific strength and comparable to these, shown by $\mathrm{Al}$ alloys and even some groups of Ti alloys and steels. What is more, magnesium alloys exhibit good technological properties, such as castability, weldability and machinabilty [2, 3]. Their main disadvantages are weak corrosion resistance and low maximum working temperatures [4]. Recently, the most widely used magnesium alloys are these with aluminium, zinc and manganese additions [5]. The $\mathrm{Mg}$ alloys found a significant interest of aerospace and automotive industries as engine housings, transmission cases, gearbox housings etc [6, 7]. The $\mathrm{Mg}-\mathrm{Al}$ alloys exhibit good mechanical properties up to $150^{\circ} \mathrm{C}$ [8]. In higher temperatures the metastable $\mathrm{Mg}_{17} \mathrm{Al}_{12}$ phase, occurring on the grain boundaries, starts to decompose $[5,6,9,16]$. It leads to significant drop of mechanical properties at the elevated temperature [8]. The working temperature of the engine elements, even in their cold parts often exceed $150^{\circ} \mathrm{C}$. This led to development of two new groups of $\mathrm{Mg}$ alloys: with $\mathrm{Al}, \mathrm{Ca}$ and $\mathrm{Sr}$ additions (up to 180 or even $250^{\circ} \mathrm{C}$ ) $[10,11]$ or with $\mathrm{RE}, \mathrm{Zn}$ and $\mathrm{Zr}$ additions (up to $250^{\circ} \mathrm{C}$ and higher) $[5,8,9]$. The creep resistance of these alloys is provided by formation of thermally stable phases at the grain boundaries $[9,17]$.

Due to hexagonal structure of magnesium, requiring high temperature for forming, the majority of elements made of magnesium alloys are produced by means of sand or die casting [12]. The required mechanical properties of the castings are achieved after grain refinement of the alloys. Structure refinement of the Mg-RE alloys can be achieved by casting at temperature of liquid metal just above the liquidus temperature or intensive 
stirring before the pouring process. However, the strongest refinement is achieved after introducing zirconium to the alloy [1]. Zirconium, which has similar cell parameters to $\mathrm{Mg}$, acts as heterogeneous nuclei of crystallization, but just if the $\mathrm{Zr}$ particle is small enough ( 1 to $5 \mu \mathrm{m})$. Refinement of the structure may also lead to formation of continous net of Mg-RE intermetallic phases at the grain boundaries, which increase alloy corrosion resistance [2]. Addition of rare earth elements reduces alloy susceptibility to shrinkage porosity formation and castings hot cracking [5]. Despite good casting properties - good dimension accuracy and and small solidification shrinkage, magnesium is extremely difficult to cast because of dramatic oxygenation in liquid state [4, $6,8,13]$. It leads to formation of non-metallic inclusion present in the structure of the castings. They strongly reduce fluidity of the alloy, as well as mechanical properties and corrosion resistance $[13,14]$. The shrinkage porosity occurring in the casting significantly decrease casting mechanical properties and fatigue resistance [15]

\section{Material for research and methodology}

The aim of the research was to investigate influence of the applied mould components on the microstructure and quality of the castings made from Elektron 21 magnesium alloy. Chemical composition of the alloy is given in the table 1 .

Table 1.

Elektron 21 alloy chemical composition (wt. \%)

\begin{tabular}{ccccc}
\hline $\mathrm{Mg}$ & $\mathrm{Zn}$ & $\mathrm{Nd}$ & $\mathrm{Gd}$ & $\mathrm{Zr}$ \\
\hline Bal. & 0.37 & 2.9 & 1.27 & 0.61 \\
\hline
\end{tabular}

Six 100x50x20mm plates have been sand cast for the research. Casting pattern with numbered plates is schematically shown in the fig 1. Plate No. 1 is surrounded by mould sand. $20 \mathrm{~mm}$ and $40 \mathrm{~mm}$ cast iron chills are applied in, in turn, plate No.2 and No.6. Plate No.3 is characterized by application of chill $20 \mathrm{~mm}$ thick and a feeder, while plate No.4 by $40 \mathrm{~mm}$ thick chill and a feeder. Only the feeder is applied in plate No.5. The temperature changes in the mould cavity were recorded with thermocouples.

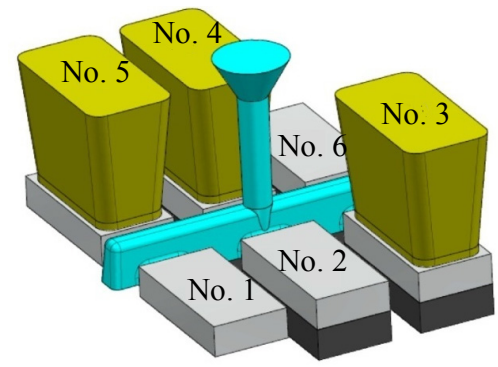

Fig. 1. Scheme of the casting pattern.
The specimens for the microstructure quantitative evaluation were cut from the middle of the longer axis of symmetry of each plate, perpendicularly to the flow of liquid metal. Microstructure was investigated in three areas, shown in the fig. 2.

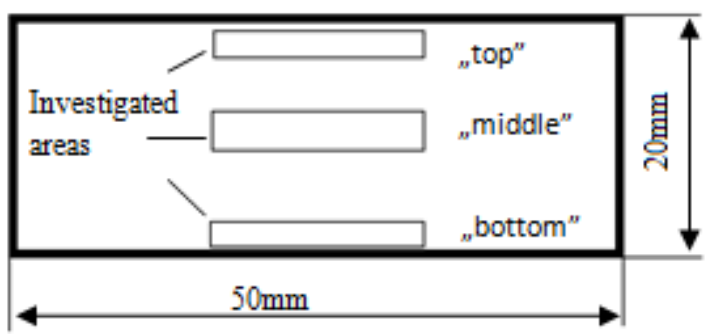

Fig. 2. Scheme of the specimens for metallographic investigation.

The casting defects were observed on similar specimens, taken from about $10 \mathrm{~mm}$ from the gating system, from the middle of the plate and about $10 \mathrm{~mm}$ from the end opposite to the gating system.

Specimens preparation consisted of grinding on the abrasive papers with gradation $320 \div 1200$, polishing on diamond pasts with mean grain size $3 \mu \mathrm{m}$ and $1 \mu \mathrm{m}$ as well as finishing polishing on the $\mathrm{Al}_{2} \mathrm{O}_{3}$ suspension. Casting defects and eutectic regions were observed on unetched microsections, while grain was observed on specimens etched in reagent containing: $4.2 \mathrm{~g}$ picric acid, $10 \mathrm{ml} \mathrm{H}_{2} \mathrm{O}, 10 \mathrm{ml} \mathrm{CH} \mathrm{CHOH}_{3}$ $70 \mathrm{ml} \mathrm{C}_{2} \mathrm{H}_{5} \mathrm{OH}$. Eutectics and $\alpha-\mathrm{Mg}$ solid solution grain were observed on Olympus GX71 light microscope in bright field technique with magnification 500 times. $\alpha$-Mg solid solution grain in the "top" area of plate No.5 was observed with magnification 200 times. Detection and quantitative evaluation were conducted in Met-Ilo software. Area of investigation was equal to $0.719 \mathrm{~mm}^{2}$ (mag. $500 \mathrm{x}$ ) or $4.38 \mathrm{~mm}^{2}$ (mag. 200x) Casting defects were observed on the Hitachi S3400N and hitachi S4200 scanning electron microscopes. Chemical composition of the non-metallic inclusions was analyzed by means of energy dispersive spectroscopy, on the Thermo-Noran EDS spectrometer.

\section{Research results}

\subsection{Microstructure}

Microstructure of the investigated alloy consists of $\alpha-\mathrm{Mg}$ solid solution grains and eutectic mixture occurring on the grain boundaries. Eutectic consists of $\alpha-\mathrm{Mg}$ solid solution and $\mathrm{Mg}_{3}(\mathrm{Nd}, \mathrm{Gd})$ intermetallic phase. Regular precipitates of $\mathrm{MgGd}_{3}$ intermetallic phase may also be observed within the grains and at the grain boundaries [9]. Volume fraction of the eutectic regions in the investigated areas is given in the table 2. Distributions of the surface area of $\alpha-\mathrm{Mg}$ solid solution grain flat section are given in the figures $3 \div 8$. 
Table 2.

Volume fraction of the eutectics in the castings made of Elektron 21 alloy

\begin{tabular}{|c|c|c|c|c|c|c|c|c|c|c|c|c|c|c|c|c|c|c|}
\hline Casting & & No. 1 & & & No. 2 & & & No. 3 & & & No. 4 & & & No. 5 & & & No. 6 & \\
\hline $\begin{array}{l}\text { Area of } \\
\text { investigation }\end{array}$ & Top & Mid. & Bot. & Top & Mid. & Bot. & Top & Mid. & Bot. & Top & Mid. & Bot. & Top & Mid. & Bot. & Top & Mid. & Bot. \\
\hline $\begin{array}{l}\text { Volume } \\
\text { fraction VV } \\
{[\%]}\end{array}$ & 1.39 & 1.75 & 1.39 & 1.74 & 1.73 & 2.25 & 0.96 & 1.06 & 1.26 & 0.96 & 0.83 & 1.32 & 1.54 & 1.46 & 1.56 & 1.83 & 1.82 & 1.94 \\
\hline $\begin{array}{l}\text { Coefficient } \\
\text { of variation } \\
v(\mathrm{VV})[\%]\end{array}$ & 24.1 & 29.5 & 29.4 & 22.3 & 12.8 & 17.4 & 26.4 & 18.3 & 19.6 & 28.5 & 25.1 & 31.3 & 36.9 & 41.7 & 46.1 & 20.5 & 19.7 & 14.0 \\
\hline
\end{tabular}

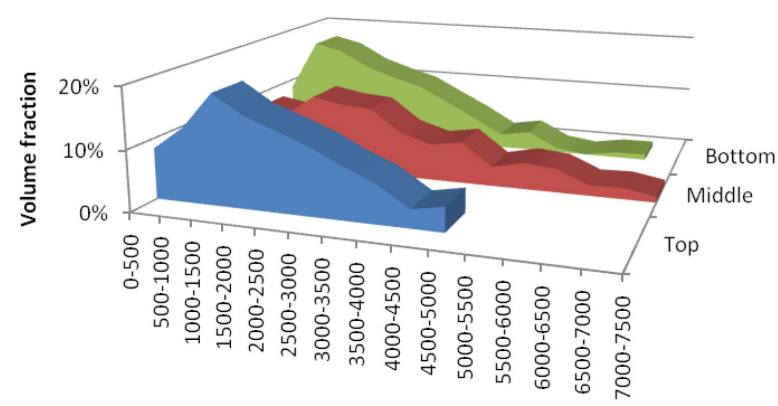

Surface area of grain flat section $\left[\mu \mathrm{m}^{2}\right]$

Fig. 3. Distribution of surface area of the grain flat section in the casting No.1.

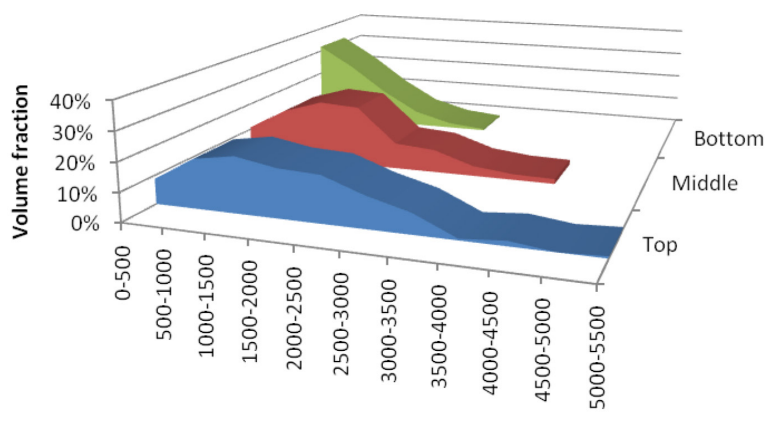

Surface area of grain flat section $\left[\mu \mathrm{m}^{2}\right]$

Fig. 4. Distribution of surface area of the grain flat section in the casting No.2.

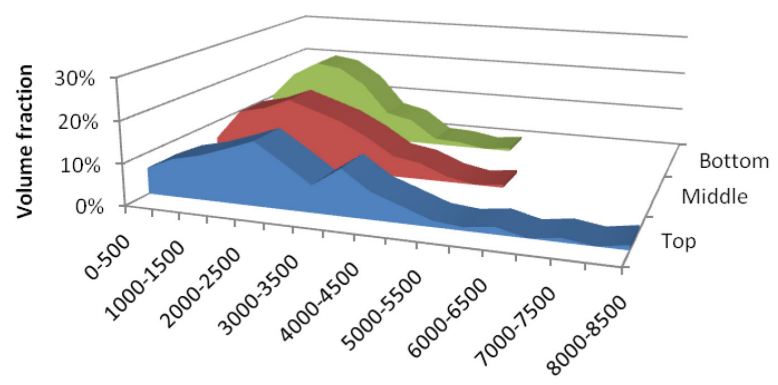

Surface area of grain flat section $\left[\mu \mathrm{m}^{2}\right]$

Fig. 5. Distribution of surface area of the grain flat section in the casting No.3.

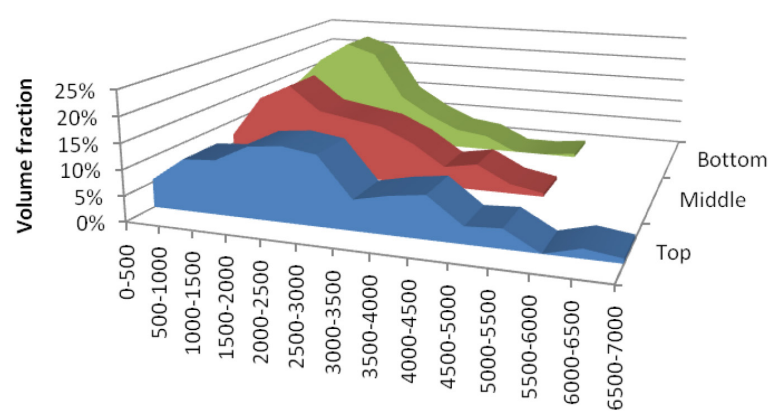

Surface area of grain flat section $\left[\mu \mathrm{m}^{2}\right]$

Fig. 6. Distribution of surface area of the grain flat section in the casting No.4. 


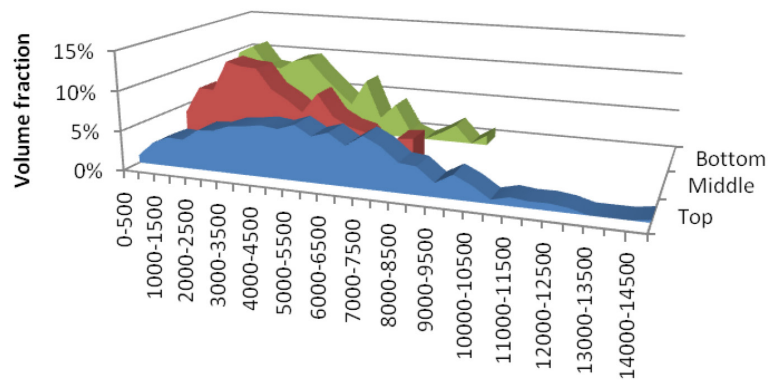

Surface area of grain flat section $\left[\mu \mathrm{m}^{2}\right]$

Fig. 7. Distribution of surface area of the grain flat section in the casting No.5

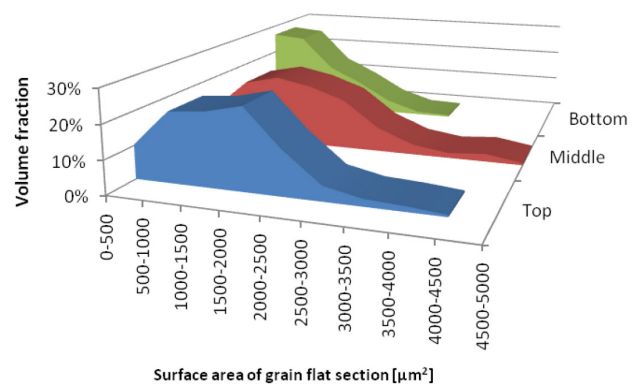

Fig. 8. Distribution of surface area of the grain flat section in the casting No.6

Average area of the $\alpha-\mathrm{Mg}$ solid solution grain flat section and average volume fraction of eutectic regions in each casting, compared with plates solidification time are shown in table 3 .

Table. 3.

Average area of the grain flat section and eutectics volume fraction, compared with solidification time of each plate

\begin{tabular}{lccc}
\hline Casting & $\begin{array}{c}\text { Solidification } \\
\text { time [s] }\end{array}$ & $\begin{array}{c}\text { Average volume } \\
\text { fraction of the } \\
\text { eutectics }[\%]\end{array}$ & $\begin{array}{c}\text { Average area of } \\
\text { the grain flat } \\
\text { section }\left[\mu \mathrm{m}^{2}\right]\end{array}$ \\
\hline No. 1 & 131 & 1.42 & 1104 \\
\hline No. 2 & 28 & 1.90 & 774 \\
\hline No. 3 & 113 & 1.09 & 1169 \\
\hline No. 4 & 104 & 1.04 & 1084 \\
\hline No. 5 & 308 & 1.52 & 2172 \\
\hline No. 6 & 27 & 1.86 & 784 \\
\hline
\end{tabular}

\subsection{Porosity}

Porosity in the castings occurs only in the interdendritic spaces. The shrinkage porosity is observed in each casting.
However in the plates with feeders applied (no. 3, 4 and 5) only small, single agglomerations of the pores are observed (Fig 9.). In the rest of the castings vast, even few square millimetres big microshrinkages were observed (Fig. 10).

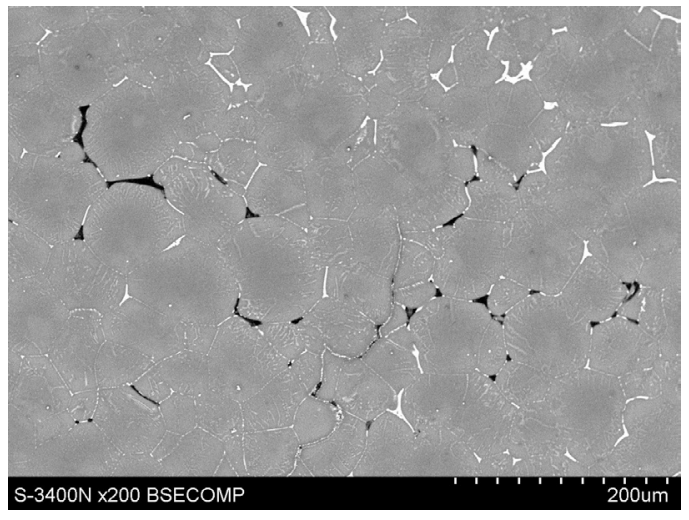

Fig. 9. Shrinkage porosity in the casting no 5, SEM, BSE

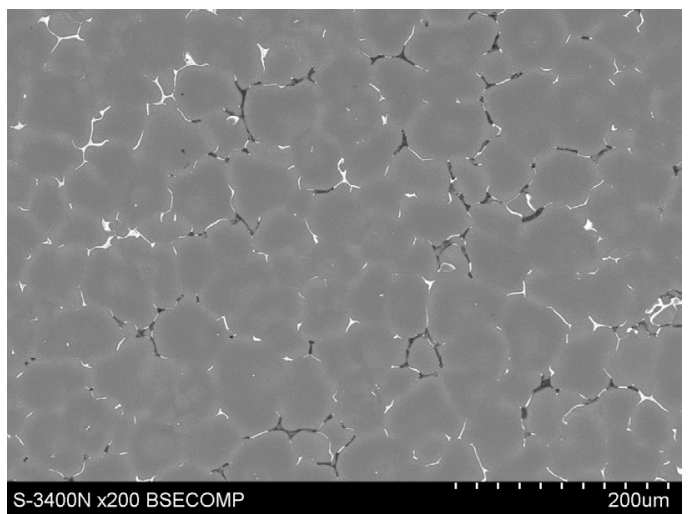

Fig. 10 Microshrinkage in the casting No.6, SEM, BSE

\subsection{Non-metallic inclusions}

Non-metallic inclusions were also observed in each casting. Four types of the inclusions were found during the investigation. First type are inclusions originating in oxygenated surface of liquid metal (Fig. 11). They occur as very thin long, thread-like impurities, with fine, regular precipitates observed near them. The chemical composition of these inclusions consists of alloying elements and oxygen, sometimes sulphur is observed.

Inclusions originating in mould material $\left(\mathrm{SiO}_{2}\right)$ has also been observed (Fig. 12). Third group of impurities are ones, coming from not completely dissolved $\mathrm{Mg}-\mathrm{Zr}$ master alloy. They are observed as thin thread-like inclusions (Fig 13) or agglomerations of fine $\mathrm{Zr}$ particles. Last one type of impurities comes from fluxes covering surface of liquid metal in the crucible, they consist of elements such as: $\mathrm{Cl}, \mathrm{S}, \mathrm{Ba}, \mathrm{Ca}, \mathrm{K}$ etc (Fig. 14). 


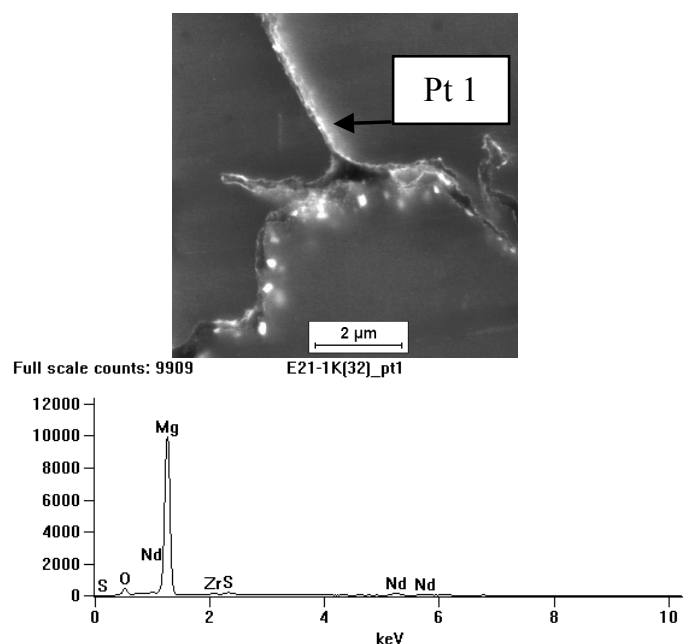

Fig. 11. Oxides in the structure of the Elektron 21 alloy

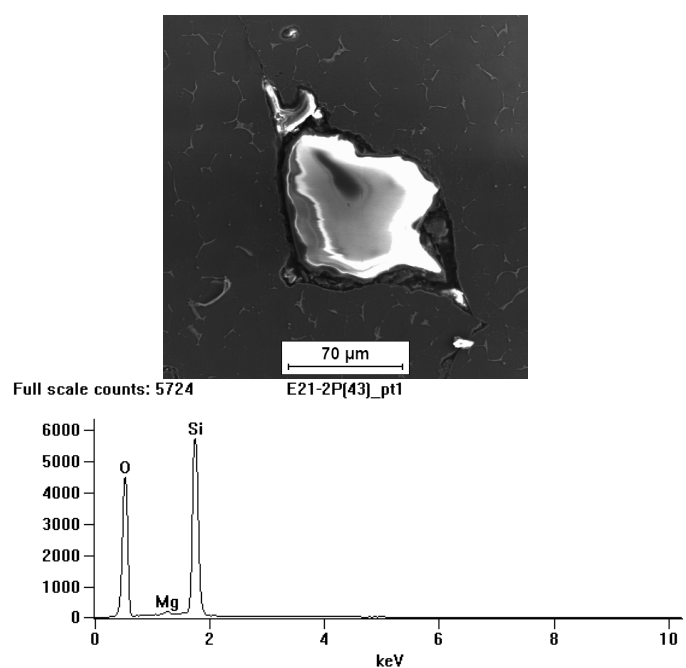

Fig. 12. $\mathrm{SiO}_{2}$ inclusions in the Elektron 21 alloy

Table 4.

Influence of the applied mould components on the average area of the $\alpha$-Mg solid solution grain flat section in each casting.

\begin{tabular}{ccccccc}
\hline Casting & No. 1 & No. 2 & No. 3 & No. 4 & No. 5 & No. 6 \\
\hline & Mould & Mould & Feeder & Feeder & Feeder & Mould \\
\hline Top & $1095 \mu \mathrm{m}^{2}$ & $911 \mu \mathrm{m}^{2}$ & $1362 \mu \mathrm{m}^{2}$ & $1322 \mu \mathrm{m}^{2}$ & $3292 \mu \mathrm{m}^{2}$ & $816 \mu \mathrm{m}^{2}$ \\
\hline Middle & $1214 \mu \mathrm{m}^{2}$ & $861 \mu \mathrm{m}^{2}$ & $1202 \mu \mathrm{m}^{2}$ & $1101 \mu \mathrm{m}^{2}$ & $1683 \mu \mathrm{m}^{2}$ & $872 \mu \mathrm{m}^{2}$ \\
\hline Bottom & $1003 \mu \mathrm{m}^{2}$ & $550 \mu \mathrm{m}^{2}$ & $944 \mu \mathrm{m}^{2}$ & $829 \mu \mathrm{m}^{2}$ & $1541 \mu \mathrm{m}^{2}$ & $665 \mu \mathrm{m}^{2}$ \\
\hline & Mould & Chill $20 \mathrm{~mm}$ thick & Chill $20 \mathrm{~mm}$ thick & Chill $40 \mathrm{~mm}$ thick & Mould & Chill $40 \mathrm{~mm}$ thick
\end{tabular}

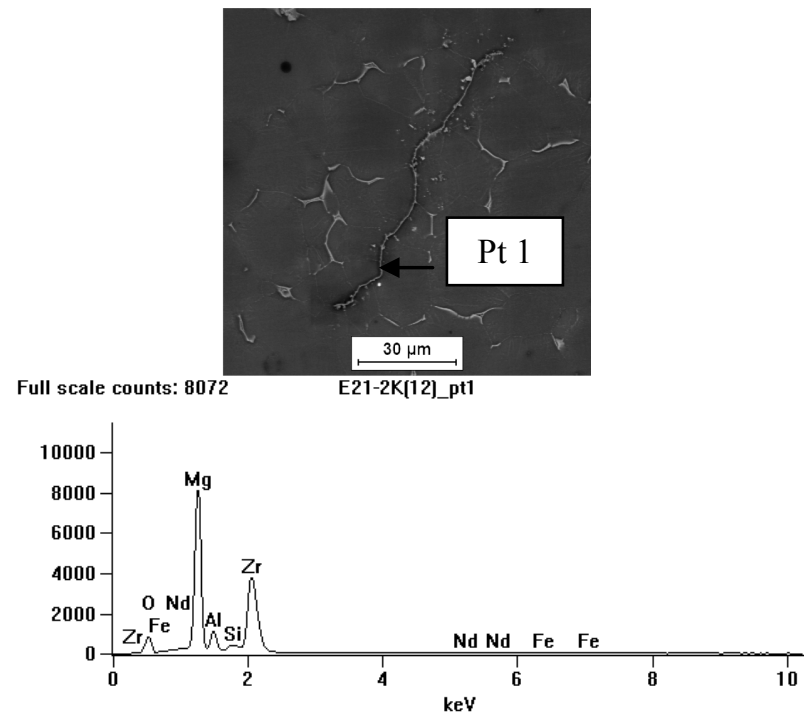

Fig. 13. Zr enriched impurities

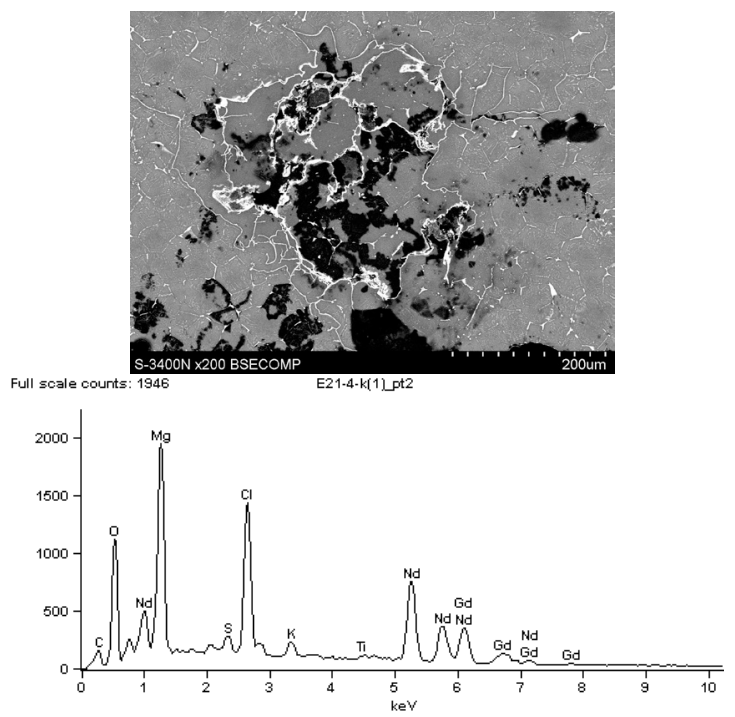

Fig. 14. Imputites originating in the fluxes and examplary EDS chart of them 


\section{Results discussion}

The average surface area of the $\alpha-\mathrm{Mg}$ solid solution grain flat section decreases with decreasing solidification time, while average volume fraction of eutectics do not depends on the cooling rate (Tab. 3).

The most heterogeneous grain is observed in the regions, in which solidification last for the longest time - core of the plate No.1 (Fig. 3) and vicinity of the feeders in castings No.3, 4 and 5

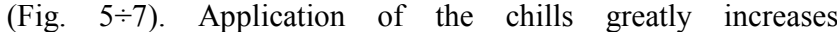
homogeneity of the Elektron 21 structure. In each plate with both the chill and feeder applied, areas neighbouring with them are characterized by nearly normal distribution of the $\alpha-\mathrm{Mg}$ solid solution grain flat section with the maximum volume fraction (about $20 \%$ ) of grains with the area of flat section equal 1000 $1500 \mu \mathrm{m}^{2}$ (plate No.3 and 4). In the plates with only the chills applied, in the vicinity of chill, the majority of grains (about $30 \%$ ) is characterized by the area of flat section up to $500 \mu \mathrm{m}^{2}$. In both cases (plate No.2 and 6) in these areas maximum area of flat section is equal about $3500 \mu \mathrm{m}^{2}$. The range overcooling effect is significantly reduced by the application of feeder. In the plates with only the chills applied both distribution of area of grain flat section and average area of grain flat section in the regions far from the chills are different, with smaller grain in the plate No.6with thicker chill applied. In the plates with the chill and the feeder applied, these differences disappear (Tab. 4, Fig. 4 and 3).

The cast iron chills increases the heat abstraction rate in the mould, enhancing the overcooling effect. It leads to creating a bigger number of nuclei of crystallization, which are afterwards distributed in the whole mould cavity be means of mechanical transport (with liquid metal flow) or convection forces. Application of feeders greatly increase size of the mould cavity, where the nuclei of crystallization are distributed. What is more, the presence of a big volume of hot, liquid metal in the feeder, increase the temperature of the mould, reducing the heat abstraction rate in the mould.

The shrinkage porosity of the castings always occurs in the regions, which solidify at last. These are: core of the casting No.1, vicinity of gating system in the casting No.2 and 6 and vicinity of feeders. Significant increase of size and number of microshrinkages is observed in the plates without the feeders applied. Low heat capacity of magnesium alloys leads to quick solidification, which shortens the time of feeding the interdendritic regions solidificating at last. Low density of the magnesium alloys and consequently, low potent energy of the liquid alloy causes further difficulties in the feeding of interdendritic regions. It leads to necessity of feeder application, which prolong solidification time and provide liquid metal to fill the voids between solidified the $\alpha-\mathrm{Mg}$ solid solution grains.

Many impurities observed in the castings origin outside the mould cavity - fluxes in the crucible or oxygenated liquid metal. Their presence in the mould can be avoided by application of strainer cores in the gating system.

\section{Conclusions}

1. Porosity of the castings is significantly reduced by the feeders application. Castings without the feeders are characterized by vast microshrinkages.

2. Impurities coming from: fluxes, mould material, not complete dissolution of $\mathrm{Mg}-\mathrm{Zr}$ master alloy and oxygenated surface of liquid metal are observed in the castings.

3. The average area of the $\alpha-\mathrm{Mg}$ solid solution grain flat section decrease according to sequence: regions in the vicinity of feeders $>$ plates cores $>$ regions near the mould sand $>$ regions in vicinity of the chills.

4. Range of chill influence on the microstructure is significantly reduced by application of feeder. In the plates with different chills and a feeder applied, no differences in the structure of Elektron 21 alloy are being observed in the top parts of plates.

\section{Acknowledgment}

The present work was supported by the National Centre for Research and Development under the research project No 6ZR7 2009C/07354.

\section{References}

[1] Das, A., Liu, G. \& Fan, Z. (2006). Investigation on the microstructural refinement of an $\mathrm{Mg}-6 \mathrm{wt} \% \mathrm{Zn}$ alloy. Materials Science and Engineering. 419(A), 349-356, DOI: 10.1016/J.Msea.2006.01.023.

[2] Sun, M., Wu, G., Wang, W. \& Ding, W. (2009). Effect of Zr on the microstructure, mechanical properties and corrosion resistance of $\mathrm{Mg}-10 \mathrm{Gd}-3 \mathrm{Y}$ magnesium alloy. Materials Science and Engineering. 523(A), 145-151, DOI: 10.1016/J. Msea.2009.06.002.

[3] Adamiec, J. \& Kierzek A. (2010), Influence of heat treatment on susceptibility to hot cracking of magnesium aloy ENMCMgRE3Zn2Zr. Archives of Metallurgy and Materials. 55(1), 69-78

[4] Mola, R. (2013). Fabrication and microstructure of layers containing intermetallic phases on magnesium. Archives of Foundry Engineering. 13(1), 99-102. DOI: 10.2478/afe2013-0019.

[5] Rzychoń, T., Szala, J. \& Kiełbus A. (2012). Microstructure, castability, microstructural stability and mechanical properties of ZRE1 magnesium alloy. Archives of Metallurgy and Materials. 57(1), 245-252, DOI: 10.2478/V10172-0120018-3.

[6] Dobrzański, L.A. \& Król M. (2013). Structure and properties investigation of MCMgAl12Zn1 magnesium alloy. Archives of Foundry Engineering. 13(1), 9-14. DOI: 10.2478/afe2013-0002.

[7] Wang, J.G., Hsiung, L.M. \& Nieh, T.G., Mabuchi M. (2001). Creep of a heat treated Mg-4Y-3RE Alloy. Materials Science And Engineering. 315(A), 81-88. 
[8] Lichý, P. \& Cagala, M. (2012). Microstructure and thermomechanical properties of magnesium alloys castings. Archives of Foundry Engineering. 12(2), 49-54. DOI: 10.2478/afe-2013-0002.

[9] Kiełbus, A. \& Rzychoń T. (2011). The intermetallic phases in sand casting magnesium alloys for elevated temperature. Materials Science Forum. 690, 214-217, DOI: 10.4028/ Www.Scientific.Net/MSF.690.214.

[10] Rzychoń, T. (2013). Methodology for the quantitative evaluation of the structure in cast magnesium alloys. Advanced Structured Materials. 32, 87-96.

[11] Rzychoń, T., Kiełbus, A. \& Dercz, G. (2010). Structure refinement of the multi-phase $\mathrm{Mg}-\mathrm{Al}-\mathrm{Sr}$ alloy. Solid State Phenomena. 163, 169-172, DOI: 10.4028/Www.Scientific. Net/SSP.163.169.

[12] Pachla, W., Mazur, A., Skiba J., Kulczyk, M. \& Przybysz, S. (2012). Wrought magnesium alloys ZM21, ZW3 and WE43 processed by hydrostatic extrusion with back pressure. Archives of Metallurgy and Materials. 57(2), 485-493, DOI: 10.2478/V10172-012-0050-3.
[13] Wang, J., Zhou, J., Tong, W. \& Yang, Y. (2010). Effect of purification treatment on properties of $\mathrm{Mg}-\mathrm{Gd}-\mathrm{Y}-\mathrm{Zr}$ alloy. Trans. Nonferrous Met. Soc. of China. 20, 1235-1239, DOI: 10.1016/S1003-6326(09)60284-3.

[14] Liang, M., Wu, G., Ding, W. \& Wang, W. (2011). Effect of inclusion on service properties of GW103K magnesium alloy. Trans. Nonferrous Met. Soc. of China. 21, 717-724, DOI: 10.1016/S1003-6326(11)60771-1.

[15] Mayer, H., Papakyriacou, M., Zettl, B. \& Stanzl-Tshegg, S. E. (2003). Influence of porosity on the fatigue limit of die cast magnesium and aluminium alloys. International Journal of Fatigue. 25, 245-256.

[16] Żydek, A., Kamieniak, J. \& Braszczyńska-Malik, K. N. (2011). Microstructural stability of Mg-5Al-0.4Mn-3RE alloy during annealing. Archives of Foundry Engineering. 11(4), 163-166.

[17] Rzychoń, T. (2010). Quantitative procedure for evaluation of microstructure of cast $\mathrm{Mg}-\mathrm{Al}-\mathrm{Ca}-\mathrm{Sr}$ magnesium alloy. Archives of Foundry Engineering. 10(1), 139-142. 